\title{
CAUSES OF ASSULTATIVE BEHAVIOR AMONG PATIENTS WITH PSYCHOSIS- DECONSTRUCTING THE SYNDROM OF VIOLENCE
}

JAN VEVERA ${ }^{1,2,4}$, ANDREA NICHTOVÁ2,3,4, LADISLAV KAŽMÉR ${ }^{2,}$, KATEŘINA PŘÍHODOVÁ2, TEREZA PŘíHODOVÁ2 , VERONIKA JURÍČKOVÁ ${ }^{2}$,

1,DEPARTMENT OF PSYCHIATRY , FACULTY OF MEDICINE AND UNIVERSITY HOSPITAL, CHARLES UNIVERSITY IN PILSEN, ${ }^{2}$ NATIONAL INSTITUTE OF MENTAL HEALTH, TOPOLOVÁ 748, 25067 KLECANY, 'PPSYCHIATRIC HOSPITAL BOHNICE, ÚSTAVNÍ $91,{ }^{4}{ }^{\text {st }}$ FACULTY OF OF MEDICINE, CHARLES UNIVERSITY

This study examined factors motivating patient aggression upon the admission to the wards of one university and two state hospitals.

Methods: The authors used a semi structured interview "The Assaults Interview Checklist" to elicit reasons for assaults from assailants and their treating psychiatrist and nurses (who were most often victims of the attacks). Based on this interview Aggressive episodes were categorized as impulsive, planed, or psychotic. Further, factor analysis was conducted to revealed latent variables.

Results: A total of 448 assaults committed by 188 newly admitted inpatients were evaluated. The majority of patients were aggressive during the first day of their hospitalization. All participants were Caucasian and spoke Czech as their primary language. Consensus clinical ratings indicated that $58 \%$ of the assaults were directly driven by positive psychotic symptoms, $16 \%$ were evaluated as a combination of the psychotic and disordered impulse control symptoms and $26 \%$ of all attacks were labeled as impulsive. Only 4 assaults were planned $(0,2 \%)$.

Conclusions: These findings indicate that assaultive behavior among hospitals in patients with psychosis is primary driven by psychotic symptoms and disordered impulse control. Because each type of assault requires a different management, characterizing aggressive behavior is crucial in determining treatment interventions. While antipsychotics are essential for persistent psychotic attacks, anxiolytics and psychotherapeutic treatment might be used for acute impulsive attacks

\begin{tabular}{|c|c|c|}
\hline & \multicolumn{2}{|c|}{ Patients $\mathrm{N}=188$} \\
$\begin{array}{c}\text { The main } \\
\text { motivational } \\
\text { influence }\end{array}$ & $\begin{array}{c}\text { Number of } \\
\text { attacks }\end{array}$ & $\%$ \\
\hline Psychosis & 258 & $57,60 \%$ \\
\hline $\begin{array}{c}\text { Psychosis } \\
\text { Impulsivity }\end{array}$ & 73 & $16,3 \%$ \\
\hline Impulsivity & 116 & $25,90 \%$ \\
\hline Planned & 1 & $0,20 \%$ \\
\hline Total & 448 & $100 \%$ \\
\hline
\end{tabular}

The Assaults Interview Checklist

\begin{tabular}{|c|c|c|}
\hline \multicolumn{2}{|r|}{ Variables } & \multirow[b]{2}{*}{$25.7 \%$} \\
\hline (1) & Hallucinations & \\
\hline (2) & Delusions & $60.3 \%$ \\
\hline (3) & Psychotic misinterpretation & $58.3 \%$ \\
\hline (4) & Provocation a) & $42.2 \%$ \\
\hline (5) & Remorse & $59.8 \%$ \\
\hline (6) & Amnesia & $38.6 \%$ \\
\hline (7) & Partial denial & $20.0 \%$ \\
\hline (8) & Psychopathy b) & $0.9 \%$ \\
\hline $\begin{array}{ll}\text { a) } & \text { i } \\
\text { i } \\
\text { d }\end{array}$ & \multicolumn{2}{|c|}{$\begin{array}{l}\text { The occurrence of at least one of three } \\
\text { items : provoked by the victim, ordered to } \\
\text { do something, request refused. }\end{array}$} \\
\hline b) $]$ & $\begin{array}{l}\text { e occurrence of at least one of } \\
\text { lanned attack 2. predatory gai }\end{array}$ & 0 items \\
\hline
\end{tabular}

Grant support AZV 17-32445A 